University of Pennsylvania Carey Law School

Penn Law: Legal Scholarship Repository

Faculty Scholarship at Penn Law

$1-2006$

\title{
Management-Based Strategies for Improving Private Sector Environmental Performance
}

\author{
Cary Coglianese \\ University of Pennsylvania Carey Law School \\ Jennifer Nash \\ Harvard University John F. Kennedy School of Government
}

Follow this and additional works at: https://scholarship.law.upenn.edu/faculty_scholarship

Part of the Administrative Law Commons, Business Administration, Management, and Operations Commons, Business Organizations Law Commons, Environmental Law Commons, and the Public Affairs, Public Policy and Public Administration Commons

\section{Repository Citation}

Coglianese, Cary and Nash, Jennifer, "Management-Based Strategies for Improving Private Sector Environmental Performance" (2006). Faculty Scholarship at Penn Law. 105.

https://scholarship.law.upenn.edu/faculty_scholarship/105

This Article is brought to you for free and open access by Penn Law: Legal Scholarship Repository. It has been accepted for inclusion in Faculty Scholarship at Penn Law by an authorized administrator of Penn Law: Legal Scholarship Repository. For more information, please contact PennlawlR@law.upenn.edu. 


\title{
ARTICLES
}

\section{Management-Based Strategies for Improving Private-Sector Environmental Performance}

\author{
by Cary Coglianese and Jennifer Nash
}

\begin{abstract}
Editors' Summary: Improvements in environmental quality depend in large measure on changes in private-sector management. In recognition of this fact, government and industry have begun in recent years to focus directly on shaping the internal management practices of private firms. New managementbased strategies can take many forms, but unlike conventional regulatory approaches they are linked by their distinctive focus on management practices rather than on environmental technologies or emissions targets. This Article offers the first sustained treatment of both public-and private-sector initiatives focused specifically on improving firms' environmental management. Synthesizing the results of a conference of leading scholars and policymakers organized by the Regulatory Policy Program at Harvard University, Cary Coglianese and Jennifer Nash consider whether management-based strategies can lead to improved environmental outcomes and, if so, how they should be designed to be most effective. They report research findings showing that management-based strategies can yield improvements in industry's environmental performance, indicating that anyone concerned about environmental quality should seriously consider the use of these strategies. Nevertheless, the authors urge caution about overstating what can be accomplished through management-based strategies, as they will not always lead to significant change in private-sector firms' environmental performance. Although management-based strategies are unlikely to become the mainstay of society's approach to environmental protection, they nevertheless deserve greater consideration because of the positive contribution they can make in certain circumstances.
\end{abstract}

\section{Introduction}

Improvements in environmental quality depend in large measure on decisions made by private-sector managers. For decades, government regulators and others interested in environmental protection tried to affect these decisions by altering incentives so that businesses would achieve a desired

Cary Coglianese is Associate Professor of Public Policy at Harvard University's John F. Kennedy School of Government and Chair of the Regulatory Policy Program at the School's Center for Business and Government. His interdisciplinary research focuses on issues of regulation and administrative law, with a particular emphasis on the empirical evaluation of alternative and innovative regulatory strategies and the role of disputing and negotiation in regulatory policymaking. His work has appeared in, among other journals, the Administrative Law Review, Duke Law Journal, Law \& Society Review, Michigan Law Review, Stanford Law Review, and University of Pennsylvania Law Review. He is the founder and co-chair of the Law \& Society Association's international collaborative research network on regulatory governance, vice chair of the e-rulemaking committee of the American Bar Association's (ABA's) Administrative and Regulatory Practice Section, and vice chair of the Committee on Innovation, Management Systems, and Trading of the ABA's Section of Environment, Energy, and Resources. He has also been a visiting professor of law at Stanford University, the University of Pennsylvania, and Vanderbilt Univer- level of emissions or would adopt specified pollution control technologies. While these traditional performancebased and technology-based regulatory strategies have worked well to spur private managers to make the investments needed to reduce some of their firms' negative envi-

sity. He is a recipient of two Resources for the Future (RFF) fellowships in regulatory implementation as well as the American Political Science Association's Edward S. Corwin Award for his research on environmental litigation. He received his J.D., M.P.P., and Ph.D. from the University of Michigan and is a member of the bar of the state of Michigan and the U.S. Supreme Court.

Jennifer Nash is Director of the Regulatory Policy Program at the John F. Kennedy School of Government, Harvard University. She conducts empirical research on emerging trends in government regulation and industry self-regulation. She has published on a variety of environmental management and policy topics in journals such as: Administrative Law Review; Annual Review of Energy and the Environment; Business, Strategy, and the Environment; California Management Review; and Environment. Her current research explores the effectiveness of performance- and management-based regulatory strategies in achieving policy goals, the role of voluntary programs in improving the environmental performance of firms, and the impact of industry codes on corporate social responsibility.

Coglianese and Nash coedited Regulating From the Inside: Can Environmental Management Systems Achieve Policy Goals? (2001), the first 
ronmental impacts, ${ }^{1}$ they have tended to treat the firm itself as a "black box," imposing requirements for specific means or outcomes without regard for the overall way that firms manage their environmental impacts. ${ }^{2}$

More recently, both government and industry have begun to explore innovative alternatives that seek directly to shape the internal management practices of private firms. Rather than treating private firms as proverbial black boxes, these new strategies focus squarely on management and seek to provide incentives for firms to develop management practices that in turn can lead to improved environmental outcomes. Government and the private sector are using management-based strategies to address a broad range of environmental concerns. For example, in Massachusetts, the legislature has attempted to reduce the risks from toxic chemicals not by requiring managers of manufacturing facilities to meet emissions limits or to install pollution control technology, but instead by requiring them to engage in management effort to develop toxic use reduction plans. ${ }^{3}$ Similarly, U.S. automakers require their suppliers to adopt environmental management systems (EMS) as a requirement for doing business, ${ }^{4}$ and the American Forest and $\mathrm{Pa}-$ per Association requires its members to adopt a set of management practices directed toward sustainable forestry. ${ }^{5}$

Decisionmakers in government and the private sector are turning to management-based strategies for several reasons.

book to examine the policy implications of emerging trends in private-sector environmental management. They are currently co-editing a second volume, Leveraging the Private Sector: Management-Based Strategies for Improving Environmental Performance, to be published by RFF Press later this year and which will include the research discussed in this Article.

The authors acknowledge support from the Charles G. Koch Charitable Foundation, the U.S. Environmental Protection Agency Office of Policy, Economics, and Innovation Grant No. R-83056701, American Chemistry Council, RFF/RFF Press, the Multi-State Working Group Policy Academy, and the Center for Business and Government at the John F. Kennedy School of Government. They also appreciate research assistance by Ben Gerber and helpful comments from Terry Davies, Donald Elliott, and Tom Lyon. This Article represents the authors' synthesis of the perspectives that emerged at a 2003 workshop sponsored by the Regulatory Policy Program and does not necessarily reflect the views of all the workshop participants. In order to facilitate open dialogue at the workshop, discussion was held on a not-for-attribution basis, so statements and ideas contained in this Article are for that reason not identified here with the names of specific workshop participants. The appendix to this Article, however, contains a list of all the individuals who participated in the workshop.

1. See generally J. Clarence Davies \& Jan Mazurek, Industry INCENTIVES FOR ENVIRONMENTAL IMPROVEMENT: AN EVALUATION OF U.S. FEDERAL INITIATIVES (1996) (Report to the Global Environmental Management Initiative); Derek BoK, The State of the Nation: Government And the Quest for a Better SocIETY (1996).

2. James Salzman \& Barton H. Thompson Jr., EnvironmenTAL LAW AND Policy (2003) ("[E]nvironmental law as a whole treats factories as giant black boxes, refusing to look at what happens inside.").

3. Mass. Regs. Code tit. 310, $\$ 50.40$ (2004).

4. Press Release, Ford Motor Company, Ford Becomes First U.S. Automaker to Require Suppliers to Achieve ISO 14001 Certification (Sept. 21, 1999) (on file with author); Press Release, General Motors Corporation, General Motors Sets New Level of Environmental Performance for Suppliers (Sept. 21, 1999) (on file with author); see also R.C. Wilson, Ford Spreads the Word About Its EMS Success, 33 Pollution Engineering 6 (2001).

5. Errol Meidinger, The New Environmental Law: Forest Certification, 10 Buff. EnVTL. L.J. 211, 239 (2003); Jennifer Nash, Industry Codes of Practice: Emergence and Evolution, in New TOOLS FOR EnVironmental Protection: Education, Information, AND Voluntary Measures 235, 237 (Thomas Dietz \& Paul C. Stern eds., 2002).
These strategies take advantage of the fact that private-sector managers have the best knowledge about how to bring about appropriate changes within their organizations and industries. ${ }^{6}$ Management-based strategies seek to leverage the private sector's informational advantage by encouraging managers to identify and reduce their facilities' most significant impacts. Interest in management-based strategies is also fueled by the perception that conventional regulatory strategies may be ill-suited for addressing the environmental problems most vexing to policymakers today. For example, problems such as chemical accidents, which are often the result of dynamic interactions inside organizations, are not easy for regulators to solve using technology- or performance-based tools. ${ }^{7}$ A management-based strategy that requires managers to identify sources of risk, develop a plan for addressing them, and monitor the implementation of their plans might be a more effective approach. Finally, people are turning to management-based strategies simply out of growing acceptance that what goes on inside the black box of the firm is of critical importance for overall environmental quality. The size of a firm's environmental footprint is not pre-determined by the raw materials it uses and the products or services it produces. Firms working in the same sector-and subject to the same competitive and regulatory pressures - can have starkly different environmental profiles depending on how they are managed.

To explore the promise and the performance of management-based strategies for environmental improvement, the Regulatory Policy Program at the John F. Kennedy School of Government at Harvard University organized a research conference that brought together some of the nation's leading scholars as well as leaders from government, business, and nongovernmental organizations. The conference aimed to evaluate experiences with management-based strategies and draw lessons for future public- and privatesector developments. This Article synthesizes and extends central themes and issues that emerged from the conference discussion and highlights unresolved issues that merit further research.

The Article begins by defining what we mean by management-based strategies and offering examples of their use by both the public and private sectors. It then turns to the role of management in organizations and explores the issue of how much management affects environmental performance compared with other social, economic, and regulatory variables. The Article next considers four empirical studies of the impact of different applications of management-based strategies. The results of this research suggest that management-based strategies can sometimes play a role in bringing about improvements in firms' environmental performance. To be sure, the effectiveness of management-based strategies is by no means assured or always significant; their success depends on the conditions under which they are used as well as the way that they are designed. Important design considerations include the incentives that are offered; whether the strategy seeks to promote management plan-

6. Cary Coglianese \& David Lazer, Management-Based Regulation: Prescribing Private Management to Achieve Public Goals, 37 LAW \& Soc'y REv. 691, 695 (2003) (management-based approaches "place responsibility for [decisionmaking] with those who possess the most information about risks and potential control methods").

7. Charles Perrow, Normal Accidents: Living With HighRisk Technologies (1984). 
ning by itself or also the implementation of plans; the specificity of any standards for management practices; the amount and type of information collected by the firm and shared with outsiders; the role of auditing; and the nature and level of community involvement. The Article concludes by examining the question of when management-based strategies are likely to be more effective than traditional performance- and technology-based approaches.

\section{What Are Management-Based Strategies?}

Management refers to the coordination of an organization's operational activities toward a specified set of objectives. ${ }^{8}$ It includes practices such as planning, goal setting, staffing, training, analysis, and control. Such management practices have long been used by businesses and are by now ubiquitous throughout industry. Every day, private-sector managers use planning, monitoring, analysis, training, and control to achieve business objectives such as improving the efficiency of their operations or the quality of their products and services.

What we call management-based strategies are attempts to require or encourage a set of targeted firms or organizations to use basic management practices in ways that align their actions and outcomes with broader social objectives. Management-based strategies, as we define them, are used by those outside an organization to change the management practices and behaviors of those on the inside. Government regulators, for example, have used management-based strategies in a variety of important areas, including pharmaceuticals, food safety, and health care institutions. ${ }^{9}$ In the environmental domain, both government agencies and various private-sector institutions are using managementbased strategies to achieve a broad range of objectives. Examples include:

- Both the U.S. Environmental Protection Agency (EPA) and the Occupational Safety and Health Administration (OSHA) have adopted management-based regulations in an effort to prevent cata-

8. Morgan Wizel, Management: The Basics (2004).

9. In its regulation of the quality of pharmaceuticals, the U.S. Food and Drug Administration (FDA) is moving toward a management-based framework called the Pharmaceutical Current Good Manufacturing Practice, which when finalized will seek to encourage industry managers to implement systems to identify, analyze, fix, and prevent quality problems. U.S. FoOd \& DrUg Administration, PharmaCeutical cGMPs for the 21st Century-A Risk-BAsed ApPROACH (2004), available at http://www.fda.gov/cder/gmp/gmp 2004/GMP_finalreport2004.htm (last visited Nov. 16, 2005). The FDA and the U.S. Department of Agriculture (USDA) are also using a management-based strategy to improve the safety of juice, seafood, and meat by requiring firms to implement a system called Hazards Analysis and Critical Control Point (HACCP) to identify and control pathogens. Procedures for the Safe and Sanitary Processing and Importing of Juice, 66 Fed. Reg. 6137 (Jan. 19, 2001) (codified as amended at 21 C.F.R. pt. 120); Procedures for the Safe and Sanitary Processing and Importing of Fish and Fishery Products, 60 Fed. Reg. 65095 (Dec. 18, 1995) (codified as amended at 21 C.F.R. pts. 123 and 1240); Final Rule on Pathogen Reduction and HACCP Systems, 61 Fed. Reg. 38806 (July 25, 1996). The accreditation standards for hospitals have become similarly management-based. Joint Commission on Accreditation of HealthCARe OrganiZations, Hospital Patient Safety Standards (2001), available at http://www.jcrinc.com/subscribers/perspectives.asp?durki=2973 (last visited Oct. 24, 2005); see generally Troyen A. BRENNAN \& Donald M. Berwick, New Rules: Regulation, Markets, AND the Quality of American Health Care (1995). strophic accidents at facilities that use large quantities of hazardous chemicals. ${ }^{10}$ Under these rules, industrial facilities must engage in a risk assessment of their operations, develop procedures designed to prevent accidents, and seek to make continuous improvements in the management of their operations. ${ }^{11}$

- EPA's National Environmental Performance Track, the Agency's flagship voluntary environmental program, recognizes and rewards firms that have met regulatory requirements, implemented EMS, and set goals for making further environmental improvements. ${ }^{12}$ Several states, including Texas and Virginia, have adopted similar programs. ${ }^{13}$

- The American Chemistry Council requires chemical manufacturing firms to implement a Responsible Care $^{\mathbb{B}}$ management system and have it externally verified as a condition for membership. Managers must implement management practices to engage the community, prevent pollution, and operate their plants safely, among other objectives. $^{14}$

- The International Organization for Standardization (ISO) has developed an EMS standard, known as ISO 14001, that facilities anywhere in the world can use as a guide for managing their environmental impacts. ISO 14001 calls for facilities to develop a system for setting their own firm-specific environmental performance goals, and then for assessing progress and correcting problems. ${ }^{15}$

As these examples show, management-based strategies can take a wide variety of forms and can be adopted by a variety of organizations, including government agencies, trade associations, and other standard-setting bodies. Nev-

10. Process Safety Management of Highly Hazardous Chemicals, 57 Fed. Reg. 6356 (Feb. 24, 1992) (codified as amended at 29 C.F.R. pt. 1910); Accidental Release Prevention Requirements, 61 Fed. Reg. 31668 (June 20, 1996) (codified as amended at 40 C.F.R. pt. 68); see generally Coglianese \& Lazer, supra note 6, at 698-99.

11. 57 Fed. Reg. at 6356.

12. See generally National Environmental Performance Track, Building on the Foundation, Performance Track Second Annual Progress Report (2004), available at http://www.epa. gov/performancetrack/PT_2nd_progress_rpt_FINAL.pdf (last visited Nov. 17, 2005) (also available from the ELR Guidance \& Policy Collection, ELR Order No. AD04985).

13. Memorandum of Agreement Between the Virginia Department of Environmental Quality and the U.S. Environmental Protection Agency (Apr. 24, 2002), at http://www.epa.gov/performancetrack/ states/programs/va_moa.pdf (last visited Oct. 13, 2005); Memorandum of Agreement Between the Texas Natural Resource Conservation Commission and the U.S. Environmental Protection Agency (Feb. 20, 2002), at http://www.epa.gov/performancetrack/states/ programs/tx_moa.pdf (last visited Oct. 13, 2005).

14. Andrew A. King \& Michael J. Lenox, Industry Self-Regulation Without Sanctions: The Chemical Industry's Responsible Care Program, 43 Acad. Mgmt. J. 698, 699-700 (2000).

15. Jennifer Nash et al., ISO 14001 and EPA's Region I's Startrack Program, in RESEARCH PAPERs 2, Vol. 1, ENVIRONMENT.gOV: TransForming Environmental Protection for the 21st Century 15-17 (Nat'1 Academy of Pub. Admin. 2000); Jerry Speir, EMSs and Tiered Regulation: Getting the Deal Right, in Regulating From THE INSIDE 198, 217 (Cary Coglianese \& Jennifer Nash eds., 2001) ("ISO 14001 guarantees no particular level of performance, and without supplementation, it provides no public information by which to judge an organizations performance."). 
ertheless, they share in common a clear focus on management itself. They all directly seek to influence the attention, information, authority, and financial resources of managers toward the achievement of environmental improvements, but without necessarily requiring them to achieve any specific outcomes and while also giving them the flexibility to choose their own measures to reduce their environmental impacts.

Management-based strategies can be classified into four types, depending on what kind of institution uses them and the types of incentives that accompany them. We distinguish between management-based strategies deployed by governmental and nongovernmental institutions. We then distinguish between management-based strategies that mandate management practices and those that encourage the adoption of improved environmental management. These two distinctions lead to the typology of management-based strategies shown in Figure 1. When a government agency such as EPA requires a business to strengthen its internal management, it is engaging in management-based regulation. When a private organization such as a firm or trade association imposes a similar requirement on its suppliers or members, it is issuing a management-based mandate. When government establishes a program to coax (but not require) firms to improve their environmental management, it uses management-based incentives. When a private organization initiates a similar effort to encourage others to improve their management, it is creating management-based pressure.

In these various ways, governmental and nongovernmental institutions are increasingly requiring or encouraging firms to improve their internal management practices as a way to improve their environmental performance. But are these management-based strategies in fact affecting the environmental performance of companies? Why should anyone expect that management-based strategies would lead firms to reduce their environmental footprints?

Figure 1. Types of Management-Based Strategies

\section{Governmental User Non-Governmental User}

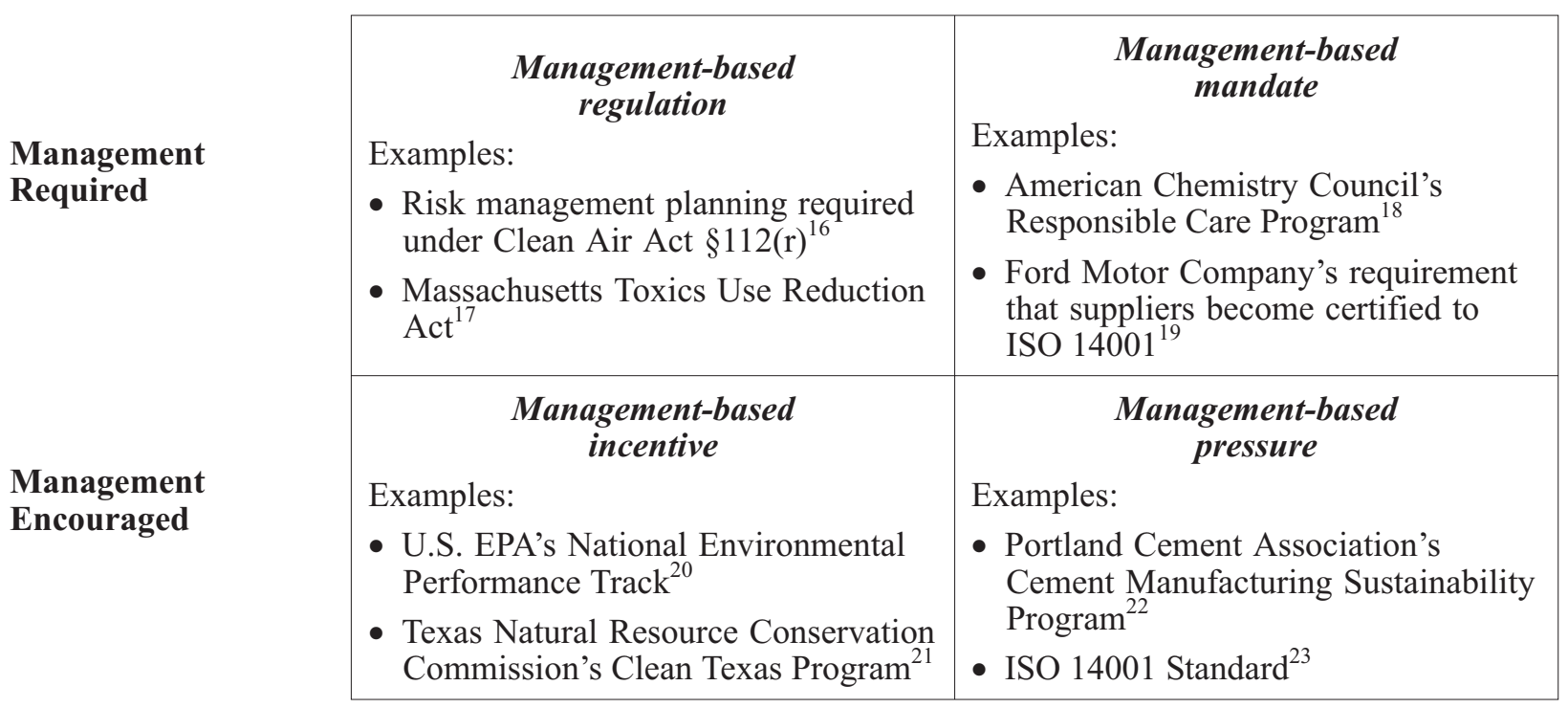

16. See supra note 10 and accompanying text.

17. See supra note 3 and accompanying text.

18. See supra note 14 and accompanying text.

19. See supra note 4 and accompanying text.

20. See supra note 12 and accompanying text.

21. Texas Natural Resource Conservation Commission, Clean Texas Cleaner World, at http://www.cleantexas.org/ (last visited Oct. 13, 2005).
22. Press Release, Portland Cement Association, Cement Industry Adopts Environmental Management Systems (Aug. 5, 2004) available at http://www.cement.org/newsroom/ems20040805.asp (last visited Oct. 13, 2005); Cement Manufacturing Sustainability Program, Plans for Future Generations (2004), available at http://www.cement.org/bookstore/profile.asp?store=\&pagenum $=$ 1\&pos=0\&catID=\&id=5728 (last visited Nov. 17, 2005).

23. International Organization for Standardization, isO 14001-Environmental Management Systems-SpecificaTION With GUidance for Use (1996). 


\section{Does Management Matter?}

In order for management-based strategies to work, management itself must be an important factor causally related to environmental outcomes. Is management the right place to look for improvements in environmental performance? How much does management matter? The opening session of the Regulatory Policy Program's conference addressed these initial questions.

The session began with a presentation by Prof. Robert A. Kagan of the University of California, Berkeley, in which he reported findings from a study of pulp and paper mills in Australia, Canada, New Zealand, and the United States. ${ }^{24}$ Professor Kagan and his research collaborators found that firms exhibited different management styles reflecting managers' attitudes toward environmental issues, their responsiveness to various pressures for environmental improvement, and the steps they took to implement environmental policies. Professor Kagan classified firms' environmental management styles into five ideal types. ${ }^{25}$ These ideal types include, on one end of the spectrum, the "true believers" who voluntarily invest in state-of-the-art practices and actively search for ways to improve their performance even beyond what they are required to do by law. At the other end of the spectrum lie "environmental laggards" who resist even complying with their basic legal obligations. In between these two extremes are "environmental strategists," "committed compliers," and "reluctant compliers," each of whom have varying degrees of commitment to excellence in managing their operations in ways that go beyond what they are required to do by law.

Professor Kagan has found that management style is an important factor influencing environmental performance. Not surprisingly, true believers and environmental strategists achieve better environmental results than those that do not comply with regulations or only comply reluctantly. Firms that are committed and systematic about managing their environmental impacts tend to perform better in terms of their impact on environmental quality than firms that are not so managed, all other things being equal.

Of course, all other things are not always equal. Firms' environmental performance is affected by more than just management style. Both performance and style itself can be affected by community demands, regulatory enforcement, and economic considerations, such as the financial strength of the company or its customers' demands for environmental quality. The importance of these factors was confirmed not only by the Kagan study of pulp and paper facilities, but also by the findings from an extensive statistical analysis presented at the conference by Prof. Paul R. Kleindorfer of the University of Pennsylvania. ${ }^{26}$ Drawing on an analysis of nearly 2,000 chemical accidents at more than 15,000 chemical facilities, Professor Kleindorfer reported that

24. See Robert A. Kagan, Environmental Management Style and Corporate Environmental Performance, in Leveraging the Private Sector: Management-Based Strategies for Improving EnVIronmental Performance (Cary Coglianese \& Jennifer Nash eds., 2006) [hereinafter Leveraging the Private Sector]; see also Robert A. Kagan et al., Shades of Green: Business, ReguLATION, AND ENVIRONMENT (2003).

25. Leveraging the Private Sector, supra note 24; Kagan et al., supra note 24.

26. See Paul R. Kleindorfer, The RMP Rule and Management-Based Regulations, in LeVeraging the Private SeCtor, supra note 24. economic, regulatory, and community factors are all important drivers of accident and injury rates in this important industrial sector. ${ }^{27}$

The research presented at the conference highlighted three important, but as yet unanswered, questions that hold clear implications for understanding and use of management-based strategies. First, why do firms vary in their environmental management style? In other words, why are some managers true believers or environmental strategists who treat environmental management as a high priority, while others are only reluctant compliers? This is a crucial question for anyone interested in management-based strategies, since such strategies aim at improving firms' environmental management. One answer, of course, is that the enforcement of old-style regulations affects managers' environmental priorities and commitment. Although traditional regulation may treat firms as black boxes, it nevertheless provides strong incentives for firms to improve their environmental management. Some firms that are now widely perceived to be environmental leaders were previously the targets of major regulatory enforcement actions that helped their managers "wake up" to the environmental aspects of their operations. ${ }^{28}$

Participants mentioned a range of additional factors that may explain why some firms take environmental management more seriously than others. These factors include: the personal beliefs of corporations' top managers; the social pressures that they face in their personal lives or in their communities, including the impact of consumer boycotts or community protests; the strategic position firms face within their sectors; and the extent to which firms' managers believe there is a strong business case for sound environmental management. ${ }^{29}$ A few participants expressed the view that management style is largely idiosyncratic, determined mainly by who is sitting at the top of a company's hierarchy and what that person figuratively "had for lunch" on any given day.

Second, what is the relative importance of each of the social, economic, regulatory, and management factors that affect firms' environmental performance? While conference participants recognized that each of these types of factors shapes managers' actions, some factors are likely to be more important than others. A few conference participants expressed the view that an often unobservable factor - managers' attitudes or commitment - might be the most important factor because it not only directly affects the seriousness of a firm's management practices, but it may also serve as a filter through which managers and their employees differentially perceive the impact of the other factors, such as community, regulatory, and financial pressures. An important but still unresolved issue for research will be to assess the degree to which management practices and managers' commitment independently contribute as much as other factors do to a firm's environmental performance.

27. Id.

28. See, e.g., Cary Coglianese \& Jennifer Nash, Environmental Management Systems and the New Policy Agenda, in REgulating From THE INSIDE 1, 2 (Cary Coglianese \& Jennifer Nash eds., 2001) (discussing "[t]he experience of the Louisiana-Pacific Corporation").

29. For general discussion of such factors, see KAGAN ET AL., supra note 24; Aseem Prakash, Greening of the Firm: The Politics of Corporate Environmentalism (2000); Forest Reinhardt, Down to Earth: Applying Business Principles to EnvironMental Management (1999). 
Finally, how should researchers study the role of management in shaping firms' environmental performance? Several participants noted the need to develop reliable ways of defining and measuring management in concrete terms using observable characteristics so that researchers can test for correlation between management and environmental performance. Without such measures, it is easy to conflate managers' attitudes and their actions in describing firms' management styles, when attitudes and actions might be separate factors affecting corporate environmental performance. ${ }^{30}$ For example, the mere fact that a facility has implemented an ISO14001-compliant EMS might itself lead to improvements in firms' performance, such that the environmental impacts of firms with such EMS tend to be systematically more benign than comparable firms without such EMS. But there still could be differences among THE firms THAT HAVE AN EMS, such that those firms with both an EMS and managers with strong, pro-environment attitudes perform STILL better. As one participant with extensive experience in environmental management consulting noted, companies that implement EMS because they want to manage themselves well will experience better results than companies that are pressured to implement EMS.

Alternatively, it could be that implementing an EMS by itself makes no difference at all, and that firms with strong pro-environment attitudes improve their performance over firms without these attitudes, regardless of whether they have a formal EMS in place. One participant posited that the presence of an EMS is merely "an epiphenomenon but not the "first cause" " of most firms' performance improvements, suggesting that the same factors that motivate firms to implement an EMS could also motivate these firms to improve their environmental performance even without an EMS.

On the other hand, despite being well intentioned and having a strong commitment to the environment, many managers may be unable to make strides to reduce their firms' environmental impacts without a formal EMS in place. Performance improvements may very well depend on the interaction of both attitudes and actions.

Participants did not resolve the issue of the relative importance of attitudes versus actions, but the conference discussion did highlight the importance of this issue for those who are deciding whether to pursue managementbased strategies. After all, if the attitudes or commitment of managers matter most in affecting firms' environmental performance, then simply requiring firms to implement certain management actions will probably not lead to the expected performance improvements. If managers need to change their attitudinal commitment in order for management to matter, it may be much harder to accomplish improved firm performance through types of managementbased strategies. ${ }^{31}$

30. For a discussion of the difference between management commitment and performance, see Coglianese \& Nash, supra note 28, at 16-18.

31. Although there may be reasons to believe that managers' attitudes matter independent of certain actions, researchers face difficulties in measuring managers' attitudes directly. Since it will be socially acceptable for managers to proclaim their attitudinal commitment to environmental protection, no matter how important it really is to them, surveys and structured interviews with managers may not result in valid or accurate attitudinal measures. Fine-grained content analysis of open-ended interview questions may result in better measures of attitudes. Alternatively, one participant suggested that it is appropriate to take managers' actions into account as a way of test-

\section{The Impact of Management-Based Strategies}

Management-based strategies provide incentives for firms to engage in management actions or practices but they do not necessarily seek to change managers' attitudes. Government regulators, trade associations, and community groups who seek to encourage or require firms to improve their environmental management cannot observe or measure attitudes nearly as easily as actions. Management-based strategies therefore focus on rewarding or punishing firms based on their management practices. What impact do strategies that seek to improve management practices ultimately have on firms' environmental performance?

At the conference, presenters focused on the environmental impacts associated with management-based strategies, reporting findings from systematic studies aimed at assessing whether these strategies have had demonstrable effects on firms' environmental performance. Most of the innovative, management-based efforts at the center of these studies have been in existence for at least one decade, but until now have yet to receive any sustained empirical scrutiny. ${ }^{32}$ As a result, the empirical studies presented at the conference shed new light on a variety of prominent public and private initiatives developed over the last decade. These studies include the following:

\section{- Prof. Lori Snyder Bennear of Duke University} conducted an empirical evaluation of state laws requiring managers to develop pollution prevention plans. ${ }^{33}$ During the early 1990 s, 14 states implemented laws requiring industrial facilities to engage in planning to reduce their use of toxic chemicals. From a theoretical perspective, Professor Bennear demonstrated that management-based regulation could be effective at reducing toxic chemical releases both by changing the internal decisionmaking of the plant and through information sharing between regulated entities and the regulator. Professor Bennear also presented new empirical evidence demonstrating that plants subject to such management-based regulations have experienced greater reductions in toxic chemical releases than they would have in the absence of these regulatory initiatives. She showed that facilities subject to these regulations reduced toxic chemicals by nearly 60,000 pounds more than comparable facilities not subject to the regulations. ${ }^{34}$

- Prof. Richard N.L. Andrews of the University of North Carolina, Chapel Hill, shared findings from a

ing the validity of any attempt to ask managers about their attitudes. Such an approach would use managers' actions effectively as a way of approximating their revealed preferences about environmental protection. Yet following such an approach, another participant noted, poses its own challenges. Researchers seeking ultimately to untangle the separate effects of attitudes and actions would want to observe actions that reveal managers' attitudes but do not correlate with environmental performance. This will probably be difficult to do, since the actions of committed managers that lead to the largest improvements in environmental performance are likely to be the best signals of managers' attitudes.

32. Lori Snyder Bennear \& Cary Coglianese, Evaluating Environmental Policies, 47 Environment 22 (2005).

33. Lori Snyder Bennear, Evaluating Management-Based Regulation: A Valuable Tool in the Regulatory Toolbox?, in LEVERAGING THE Private SeCtor, supra note 24.

34. Id. 
study of management-based mandates imposed by industrial customers on their suppliers. ${ }^{35}$ Professor Andrews and his collaborators surveyed 3,200 manufacturing facilities in four sectors, comparing the self-reported environmental performance of facilities that adopted formal EMS in order to comply with customer mandates with the self-reported performance of firms that were not subject to an EMS mandate and had not implemented one. ${ }^{36}$ Their survey results suggested that the mandates led to improved performance in some aspects of firms' operations but not others. Managers in companies that had implemented an EMS in response to a business mandate reported more improvements in energy use, recycling, and reductions in spills and leaks compared with managers in companies without an EMS. No significant differences emerged, however, between companies in other aspects of environmental performance. ${ }^{37}$

- Prof. Jason Scott Johnston of the University of Pennsylvania shared the results from an empirical study of the effectiveness of EPA's Strategic Goals Program (SGP), a management-based voluntary program established between EPA and the metal finishing industry in $1998 .{ }^{38}$ SGP aimed to spur firms to adopt improved management practices and meet ambitious "beyond-compliance" performance goals. Although upward of 300 firms joined SGP and demonstrated reductions in environmental impacts compared with a 1992 baseline, Professor Johnston concluded that the impact from the SGP program itself was at best limited. SGP did help in disseminating information about pollution prevention throughout the sector, but many of the environmental improvements made by participating firms occurred before the program was launched in 1998. Moreover, the program only attracted a small percentage of all the shops in the metal finishing sector. ${ }^{39}$

- Tapas Ray and Prof. Kathleen Segerson of the University of Connecticut studied the impact of an EPA management-based effort called the Clean Charles Initiative. ${ }^{40}$ In the Clean Charles project, government served as the standard bearer of an ecosystem-wide performance management initiative that led to significant improvements in water quality on the Charles River in Boston. Ray and Professor Segerson showed how EPA's efforts to focus management attention on water quality also brought greater focus to government inspections and enforcement actions, and they argued that these

35. Richard N.L. Andrews et al., Environmental Management Under Pressure: How Do Private-Sector Mandates Affect Performance?, in Leveraging the Private Sector, supra note 24.

36. Id.

37. Id.

38. Jason Scott Johnston, The Promise and Limits of Voluntary Management-Based Reform: An Analysis of EPA's Strategic Goals Program, in Leveraging the Private Sector, supra note 24.

39. Id.

40. Tapas Ray \& Kathleen Segerson, Clean Charles 2005 Initiative: Why the "Success"?, in Leveraging the Private Sector, supra note 24 . enforcement actions taken in response to the government's goal setting played a major role in spurring improvements in environmental management and water quality. 41

Overall, these results suggest that the impacts of management-based strategies can vary from clearly positive to marginal to nonexistent. Conference discussion focused on why these strategies might work at all in those cases where they do. A key factor, according to several participants, lies with the information that management-based strategies generate. Management-based strategies generally call upon firms to invest in the production of information about the environmental risks created by their operations and about alternative mitigation measures, as well as to develop procedures for continued monitoring and information collection. The information generated through management systems leads to behavioral change either by: (1) providing feedback directly to decisionmakers within firms about ways to reduce potential liabilities; or (2) informing outsiders who in turn bring pressure to bear upon the firms' decisionmakers. ${ }^{42}$ Several participants used the oft-used expression "what gets measured, gets managed" to suggest that knowledge of any environmental problem is a necessary condition for managers to find a solution.

Management-based strategies seek to provide incentives for managers to invest in information-gathering. Without such incentives, firms may not always find it in their interest to gather the information they need to identify potential opportunities for environmental improvement, even when these opportunities might bring business advantages to the firm. ${ }^{43}$ This is because finding so-called win-win opportunities is not cost-free. Even if the expected business benefits were positive, they might not be significant enough for managers to justify spending the time and resources needed to identify the win-win options in the first place. When government agencies or customers either mandate planning or offer firms incentives to engage in such planning, firms more readily invest in the search for win-win opportunities. Once firms undertake a search for information in response to these incentives, they will be inclined to implement those opportunities they find that both benefit the environment and their bottom line.

Conference discussions also examined why management-based strategies might not work as well as some would hope. A key issue affecting the degree to which management-based strategies succeed in bringing about environmental improvement, according to many participants, is the adequacy of incentives. Several participants stressed that behavioral change requires either changed attitudes or sufficient incentives, but they questioned whether management-based strategies could generate either. Without changed attitudes or adequate incentives, firms may simply go through the motions by creating management systems that make little difference in terms of environmental outcomes. ${ }^{44}$

41. Id.

42. See Eric Orts, Reflexive Environmental Law, 89 Nw. U. L. Rev. 1227, 1232 (1995).

43. Coglianese \& Lazer, supra note 6, at 703; see also Bennear, supra note 33, at 10 .

44. See Cary Coglianese, Policies to Promote Systematic Environmental Management, in Regulating From the Inside 181, 194 (Cary 
Many participants agreed that the most significant environmental improvements depend upon large capital investments or markedly different business strategies. They doubted whether any management-based strategy by itself could lead firms to make such major changes and suggested the need for government regulation to mandate the use of specific technologies or to impose stringent performance standards that necessitate that firms make significant investments or changes in their business strategies. Furthermore, many firms lack the capacity to make significant environmental improvements regardless of the incentives available through management-based strategies. Large, multinational firms often have the capacity to implement sophisticated and meaningful management systems, but similar progress probably cannot be expected of small-to-medium sized enterprises or businesses facing a high level of global competition or tight profit margins. ${ }^{45}$

A few participants expressed skepticism about the efficacy of management-based strategies due to the reluctance of the private sector to make substantial investments in environmental protection. One participant argued that private-sector initiatives, such as trade association codes of environmental management, are inherently weak because industry groups face collective action problems and have a tendency to promulgate management standards based on the lowest common denominator. Another participant suggested that even government management-based initiatives have been watered down due to pressures from industry during implementation.

Finally, the costs of implementing management systems should not be overlooked; these costs are nontrivial. For example, one participant surmised that complying with the paperwork requirements of the Clean Air Act's risk management rule - a management-based regulation - demands in the aggregate close to 100,000 hours of management time each year and costs tens of millions of dollars. ${ }^{46}$ A key question for future analysis will be whether the costs of generating information in response to management-based strategies are justified in light of the magnitude of environmental benefits that result. Ultimately, the net benefits of management-based strategies (that is, environmental benefits minus compliance costs) should be compared with the net benefits from alternative environmental strategies, including the adoption of more conventional forms of regulation.

The conference discussion addressed several potential complications and challenges for researchers wishing to study the impact of management-based strategies. A few participants suggested that absent large capital investments in pollution control technologies, the environmental improvements associated with systematic environmental management are likely to be marginal and spread across a variety of areas within a firm's operations. Consequently, researchers choosing a single measure of environmental perfor-

Coglianese \& Jennifer Nash eds., 2001) ("Policies that merely increase the use of [management systems] may do little to encourage the sustained commitment needed for firms to make ongoing environmental improvements.").

45. Cary Coglianese \& Jennifer Nash, Policy Options for Improving Environmental Management in the Private Sector, 44 ENVIRONMENT 9, 11, 16 (2002).

46. For discussion and analysis of the amount of time and money invested in paperwork requirements, see Accidental Release Prevention Requirements: Risk Management Programs Under Clean Air Act §112(r)(7), 60 Fed. Reg. 13526, 13541-45 (Mar. 13, 1995). mance may well fail to observe any dramatic impact from management-based strategies even though the cumulative effect of the individual improvements made across all areas could be significant. Similarly, several participants suggested that the impacts from management-based efforts would be less observable in the short term but more likely to occur over the longer term. This is because information generated through improved management takes time to flow throughout a firm to product designers and process engineers, and consequently the most substantial effects from management systems may not occur until the next time the company develops a new product line or production process.

The results from the studies presented at the conference indicate that management-based strategies do not always yield dramatic impacts. However, even when management-based strategies do not result in observable changes in firms' performance, this does not definitively resolve the larger question about the impact of management itself. It could be possible either that firms have not fully responded to the strategies (perhaps due to insufficient incentives) or that these strategies have simply prompted firms to adopt the wrong kind of management practices. The variation in results from across the empirical studies suggests that the impact of management-based strategies may depend ultimately on the incentives they provide to firms to improve their environmental management as well as the way these strategies are designed.

\section{The Design of Management Systems}

As we have seen, management-based strategies do not represent a single approach but actually different kinds of efforts aimed at improving companies' environmental management and performance. ${ }^{47}$ Although they share the purpose of fostering effective management, these strategies can differ along at least two major dimensions that we have described, either one of which could make a difference in the outcomes achieved. Whether the initiating institution is governmental or nongovernmental and whether improved management is required or simply encouraged will shape the ultimate impact of these management-based strategies. In addition, participants at the conference identified a variety of other potentially relevant differences in the design of management-based strategies. These other design features include:

\section{- Planning Versus Implementation. Management-} based strategies can encourage or require planning only (leaving it up to firms to decide on their own whether to implement some or all of their plans), or they can provide incentives for firms both to engage in planning and to implement their plans.

- Types of Management Actions. The types of actions required or encouraged by managementbased strategies can vary. For example, some management-based strategies call for employee training as part of the preferred management system, while others do not. Some call for managers to establish goals consistent with clearly stated performance targets, while others do not stipulate

47. $C f$. Coglianese \& Nash, supra note 28, at 229 (noting that "EMSs represent a wide range of approaches"). 
performance targets expected from managers and their goals.

- Specificity of Actions. Expectations for planning and management actions can be general or specific. For example, some state pollution-prevention planning laws call for firms to do little more than adopt "appropriate" plans, while other managementbased regulations call for firms to develop plans that meet detailed and extensive criteria.

- Information Collection. Different managementbased strategies call for firms to collect different kinds of information. In addition, there are differences in whether information and records are to be kept by the firms themselves or whether they should be released to others, including the public or government.

- Auditing. The extent of any auditing, as well as the type of auditor, can vary. Since the incentives offered by different strategies are contingent on firms taking the specified management actions, some attention to auditing is needed. Verification that firms have taken the specified actions can be conducted frequently or infrequently, on an announced or unannounced basis, and by government or third-party auditors.

- Stakeholder Involvement. Sometimes firms are expected to engage with community or environmental groups as part of their environmental management process.

A key challenge in the development of management-based approaches to environmental policy will be to identify which of these design elements, or which combinations of these elements, yield the most successful outcomes under specific conditions. In addition, when drawing inferences from empirical studies, the possible differences in the design of management-based strategies should also be taken into account. Even though a research study may show that a particular strategy does (or does not) have an observable impact on firms' environmental performance, it is possible that other strategies with different design elements will yield different results.

Participants posited three criteria or characteristics needed to make management-based strategies effective. First, the user of the strategy - such as government or a trade association - should have a clear goal in mind and communicate that goal to firms and other interested organizations. The Clean Charles Initiative provides a good example because EPA communicated a concrete goal of achieving fishable and swimmable water quality by $2005 .^{48}$

Second, an effective strategy should be tied to metrics so that firms' performance can be reliably measured and compared, both over time and across firms. If the strategy calls for actions or outcomes that are stated too loosely or cannot be meaningfully verified, then the quality of firms' management efforts will be difficult to assess for the purpose of granting a reward or imposing a punishment.

Finally, to be effective, management-based strategies need to provide firms with adequate incentives to take appropriate management measures. If the incentives are largely punitive, such as government fines or the revocation

48. Ray \& Segerson, supra note 40. of a purchasing arrangement, the threat that noncompliance will be identified and punished needs to be credible. If the incentive takes the form of rewards, the benefits firms receive must be sufficient to induce firms to undertake serious environmental efforts. As one participant put it, any carrots that are offered should also be the size of sticks - that is, their absolute value should be at least as large as that of applicable civil penalties in order to be effective.

\section{Involvement of Third Parties in Environmental Management}

The role for so-called stakeholder involvement in management-based strategies generated considerable discussion. ${ }^{49}$ Many conference participants called for a larger role for external stakeholders in the design and review of firms' EMS. These groups could help ensure that managers assess their firms' environmental impacts appropriately, set reasonable objectives and targets, devote an appropriate level of resources to implementing and maintaining the system, and put into place effective mechanisms to identify and correct performance problems. Some participants argued that involvement by community officials and organizations in a firm's environmental management could deliver important, but perhaps intangible, value to businesses. Another participant stated that private-sector managers appear increasingly to be open to involving external stakeholders in their environmental management. Management-based strategies that seek to institutionalize community involvement may succeed in creating ways to keep the pressure on firms to make continuous improvements.

A number of participants pointed to limitations in relying on stakeholder involvement. One set of problems involves identifying stakeholders: Who are the stakeholders for any given industrial facility? How should firms identify a complete or balanced group of stakeholders? One participant wondered whether the challenges associated with identifying all the relevant stakeholders would even require the creation of an "administrative law at the level of the firm," whereby firms provide public notice of changes to their management plans and provide opportunities for outsiders to comment on these plans.

A further problem is that community and environmental organizations often lack the resources to make a meaningful contribution to companies' development and implementation of management systems. ${ }^{50}$ Local groups often lack sufficient technical expertise about industrial operations, and the large, national environmental organizations that possess greater expertise lack the organizational presence and staffing needed to help design and monitor the management at facilities across the country. Furthermore, one participant from industry noted that the experts in environmental groups seldom express much interest in management per se, tending instead to focus their efforts directly on facilities' environmental performance or the adoption of specific pollution control technologies.

49. For related discussion of the role of stakeholder or community group involvement, see Robert Kagan et al., Social License and Environmental Protection: Why Businesses Go Beyond Compliance, 29 LAW \& Soc. Inquiry 307 (2004); IAN Ayres \& JoHn BraithWAithe, Responsive Regulation (1992).

50. Alfred A. Marcus et al., Reinventing Environmental Regulation Lessons From Project XL (2002). 
A paper by Prof. Andrew King, of Dartmouth's Tuck School of Business, highlighted a final problem with stakeholder involvement. ${ }^{51}$ Professor King acknowledged that environmental organizations could bring value to industry efforts to adopt innovative approaches to environmental management, particularly by signaling to others that a company's efforts are responsible. This signaling function could be particularly valuable for certain kinds of environmental risks that lack clear technological fixes or performance measures (at least short of a catastrophe). After all, what constitutes good management will often not be clear to an outside observer, such as a regulator or trade association, so the existence of stakeholder involvement in a firm's environmental management lends credibility to that firm's efforts. However, Professor King argued that the same reason stakeholders provide this credibility - namely, that their interests are not aligned with those of industry - also limits the degree to which companies may be willing to involve them in their management. ${ }^{52}$ In particular, Professor King emphasized that environmental organizations have an interest in seeing innovative industrial practices adopted at one firm diffuse throughout an industry, while businesses' interests generally lie in keeping information about their operations from their competitors. ${ }^{53}$

A related issue in designing management-based strategies centers on the auditing of firms' management practices. ${ }^{54}$ Stakeholder involvement may lend some credibility to a firm's management efforts, but if firms are to be rewarded for adopting certain management practices or punished for not doing so, it will be necessary to know which firms have acted in ways meriting reward or punishment. Who will conduct needed audits? Many participants questioned whether government agencies have sufficient resources and personnel for auditing and suggested that thirdparty auditing be considered.

Howard Kunreuther, Shelley Metzenbaum, and Peter Schmeidler presented a paper investigating the potential for linking mandatory insurance with private inspections. ${ }^{55} \mathrm{In}$ surers have incentives to conduct inspections of firms in order to make premium ratings and reduce claims. To a much greater extent than other third-party auditors, who are normally paid for their services by the audited firm, insurance companies have a strong interest in reducing risks. Furthermore, the costs of the inspections would be paid for in the premiums firms pay, thus providing a way to overcome the government's resource constraints. Kunreuther, Metzenbaum, and Schmeidler propose that pilot studies be undertaken to assess the impact of mandatory insurance on specific environmental, health, or safety problems ${ }^{56}$ They conclude that a mandatory insurance problem would not necessarily substitute for, or eliminate the need for, conventional

51. See Andrew King, The Role of Management Systems in Stakeholder Partnerships, in Leveraging The Private Sector, supra note 24.

52. $I d$.

53. Id.

54. National Academy of Public Administration, Third Party Auditing of Environmental Management Systems: U.S. Registration Practices FOR ISO 14001 (2001), available at http://www.napawash.org/pc_economy_environment/recent_ publications.html\#2001 (last visited Oct. 13, 2005).

55. See Howard Kunreuther et al., Private Inspections and Mandatory Insurance for Managing Safety and Environmental Risks, in LEVERAgING THE PRIVATE Sector, supra note 24.

56. Id. regulation and government inspections, but it could offer a complement to them. ${ }^{57}$

\section{Management-Based Strategies and Conventional Regulation}

The ultimate question surrounding management-based strategies is when to use them. Where do they fit into the existing array of policies and strategies for environmental protection? More specifically, what is their relationship to conventional regulation? ${ }^{58}$ Participants argued that management-based strategies can be used both to help firms come into full compliance with existing regulations as well as to take steps that go beyond compliance with these regulations. In addition, some suggested that management-based strategies will, on occasion, be appropriate alternatives to conventional regulation.

Management-based strategies can lead firms to improve their compliance with conventional technology and performance-based regulations by encouraging them to identify the regulations they are subject to and develop plans to come into and maintain compliance. Such compliance management systems often include regular, internal audits to identify and correct instances of noncompliance. One participant described management systems as an "insurance policy" for firms, while another explained that the firms he works with adopt EMS to avoid being "struck by lightening" when the government inspectors come to pay a visit. Other participants, though, expressed doubts about how important EMS are for ensuring compliance. For example, the study presented at the conference by Professor Andrews found no significant differences in the reported levels of compliance between firms with and without management systems, suggesting that firms can come into compliance even when they do not have formal EMS in place. ${ }^{59}$

Companies can use management systems to identify ways of reducing environmental impacts not currently addressed by government regulation. For example, the same study presented by Professor Andrews found that the presence of management systems correlated with significant improvements in reported environmental impacts on unregulated aspects of business - such as avoiding spills or conserving energy - but not on regulated aspects such as air and water emissions. ${ }^{60}$ These findings suggest the possibility that management-based strategies may be especially suited for environmental problems that call for improved operational management and internal coordination-problems that may be difficult to address through conventional regulatory strategies.

Management-based strategies implemented in the United States over the last decade have all been used against the backdrop of extensive government regulation. Several participants believed that management-based strategies only will work (or will work best) when they have a credible reg-

57. Id.

58. U.S. EPA, EPA's Strategy for Determining the Role of ENvironmental Management Systems in Regulatory ProGRAMS (2004), available at http://www.epa.gov/ems/docs/EMS and_the_Reg_Structure_41204F.pdf (last visited Oct. 24, 2005) (also available from the ELR Guidance \& Policy Collection, ELR Order No. AD04986).

59. Andrews et al., supra note 35.

60. Id. 
ulatory threat operating in the background. For example, the study by Professor Johnston suggested that firms in the metal finishing industry were motivated to participate in the SGP in order to preempt the adoption of tougher water pollution regulations that EPA had proposed in $1995 .{ }^{61}$ Government agencies can also use the existence of burdensome conventional regulation to offer rewards - namely, waivers from existing regulations - to firms that demonstrate responsible environmental management. ${ }^{62}$

Although environmental regulation has long been said to have many problems, participants pointed out that management-based strategies have their own problems, some of which might be worse than those associated with conventional regulation. One fundamental concern was that these new strategies, especially when they take the form of government requirements for certain management processes, might intrude into the core of business decisionmaking. Putting management into private hands is, after all, what a free enterprise system is all about. Government-imposed standards on environmental management could be too rigid and inflexible, especially in the face of changing conditions in global markets.

Some suggested that management is too difficult a matter for government to try to influence. Good management involves much more than a flowchart or set of procedures that exists on paper. Instead, it reflects the dynamics of organizations made up of people and their relationships with each other. Even the most informed government officials will not be as well-situated as private-sector managers to know the best way to manage businesses to return a profit and minimize impact on the environment. Moreover, government itself is far from unified, so the possibility exists that different agencies could require duplicative or incompatible management steps.

Other participants thought that requiring or encouraging firms to adopt management systems could hardly do much harm, especially if they do not call for the adoption of any new technologies or compliance with more stringent performance standards. However, these same participants also wondered whether management systems would do much good. Even though several empirical studies presented at the conference showed that management-based strategies can lead to environmental improvements, ${ }^{63}$ the substantive significance of these improvements needs to be considered. Whether the benefits achieved are worth the costs that they impose on economic activity has yet to be determined. One participant argued that if there are problems with conventional regulation, the solution should be to fix those problems - not to expect that management-based strategies will make up for the shortcomings of the existing regulatory system. Another participant expressed concern that attention to management-based strategies could be used

61. Johnston, supra note 38. See generally Thomas P. Lyon \& John W. Maxwell, "Voluntary" Approaches to Environmental Regulation, Economic Institutions and Environmental Policy, in ECONOMIC INSTITUtions and Environmental Policy (Maurizio Franzini \& Antonio Nicita eds., 2002); Kathleen Segerson \& Thomas J. Miceli, Voluntary Environmental Agreements: Good or Bad News for Environmental Protection?, 36 J. EnVTL. Econ. \& MGMT. 109 (1998).

62. National Environmental Performance Track Program, 69 Fed. Reg. 21737 (Apr. 22, 2004) (codified as amended at 40 C.F.R. pts. 63 and 262) (allowing facilities in Performance Track to store hazardous wastes on site longer than they would ordinarily be permitted).

63. Bennear, supra note 33; Andrews et al., supra note 35. to preempt other regulatory interventions that would better serve society. $^{64}$

In making decisions about management-based strategies, decisionmakers should take into account the full range of possible impacts these strategies may generate. For example, one participant suggested that one of the unintended consequences of trade association mandates has been that numerous marginal firms leave those trade associations that have imposed such mandates. A similar effect may also arise with government programs when firms take actions to bring their use of specified chemicals below levels that trigger the imposition of management-based regulation-even if doing so does not lower substantially their overall level of environmental risk. ${ }^{65}$ To address these kinds of side effects, management-based strategies should probably be combined with other efforts by government, trade associations, and community groups to keep firms shifting their operations off the radar screen.

A final concern with management-based strategies focused on issues of equity-both from the standpoint of the public as well as of industry itself. For the public, the flexibility inherent in a management-based approach may mean that the same types of facilities could emit different levels of pollution in different locales. Although conventional regulation may be criticized for taking a one-size-fits-all approach, uniform technology- or performance-based standards at least are uniform. For business, there is a separate equity concern, namely that government inspectors and others who oversee management-based programs will apply management standards in inconsistent or inequitable ways. If what counts as good management is not clearly specified, this will give discretion to auditors and may result in an uneven application of sanctions or rewards. ${ }^{66}$

Equity issues also arise from the distinction between actions and attitudes. Management-based strategies work by discriminating between firms based on whether they have in place certain easily observable management practices, and consequently these strategies will be vulnerable to criticism that firms are selected for reward or punishment based on the wrong criteria. Some firms may be rewarded simply because they go through the motions of adopting a management system, while other firms that are really making a difference in reducing pollution could go unrewarded because they lack the requisite formalities in their management practices.

Participants recognized that management-based strategies have both advantages and disadvantages. As such, no participant advocated eliminating the existing system of environmental regulation altogether in favor of adopting only management-based strategies. Rather, the challenge for decisionmakers will be to find the optimal intervention for the specific problems and circumstances they confront. In

64. For sources discussing such regulatory preemption, see supra note 61 .

65. See Lori Snyder, Essays on Facility-Level Response to Environmental Regulation (2004) (unpublished Ph.D. dissertation, Harvard University) (on file with the John F. Kennedy School of Government Library).

66. See Coglianese \& Lazer, supra note 6, at 726 ("The challenge for government enforcement of management-based regulation may be made more difficult because the same conditions that make it difficult for government to impose technological and performance standards may also tend to make it more difficult for government to determine what constitutes 'good management."'). 
some cases, the best option will be to continue to rely on conventional regulatory strategies. Yet in other cases, as some of the research papers and conference discussion suggested, there will be good reason to consider using a management-based strategy. Management-based strategies may be particularly useful in order to influence the practices of a highly diverse set of facilities, collect information that will help motivate private-sector managers or activate influential stakeholders, or improve performance among facilities or with respect to specific problems that are simply not amenable to other regulatory approaches. ${ }^{67}$

\section{Conclusion}

Management-based strategies are increasingly gaining the attention of leaders in both the public and private sectors. These strategies can take many forms, but they are linked by their emphasis on improving management and thereby seeking to contribute indirectly to improved environmental outcomes. They hold out the promise that firms will gather information needed to improve their environmental performance and that they will respond to their acquisition of this information by reducing or preventing pollution. By providing incentives for firms to identify their own risks and select their own mitigation solutions, management-based strategies are flexible and seek to use the private sector's informational advantage for the public good.

The research presented at the Regulatory Policy Program's conference suggests that while still relatively new and unstudied, management-based strategies may sometimes have a role to play in environmental protection. Management style does appear to shape the environmental performance of firms, so strategies that influence private-sector management can be considered at least plausible candidates for bringing about environmental improvements. The studies presented at the conference have broken new ground by empirically investigating the impact of management-based strategies. Some, but not all, of these studies confirm that management-based strategies can contribute to reductions in pollution. Of course, the overall impact of any strategy depends on a variety of factors, including the incentives it provides to firms to make improvements and the type of environmental problem being addressed.

The research presented at the conference adds to an emerging body of empirical knowledge about public- and private-sector strategies to leverage managers' efforts to improve environmental conditions. The conference discussion summarized in this Article has highlighted both the advantages and disadvantages of management-based strategies so that decisionmakers can have realistic expectations about what these strategies will be able to achieve. While improvements in environmental management can produce some results, this does not mean that the results will always be dramatic nor does it mean that management-based strategies will be appropriate for all problems.

Further research will be needed to inform decisionmakers interested in management-based strategies. As one participant argued, just as medicine has moved toward evidencebased practice, so too should environmental policy move closer toward evidence-based decisionmaking through

67. See generally Coglianese \& Lazer, supra note 6; Bennear, supra note 33 . greater reliance on empirical research. ${ }^{68}$ By bringing together leading researchers with key public- and privatesector leaders to discuss a variety of new empirical studies, the Regulatory Policy Program's conference has shed light on an emerging approach toward environmental protection and provided a foundation upon which future research can be based.

\section{Appendix \\ Conference Participants}

Richard N.L. Andrews

Professor of Environmental Policy

University of North Carolina, Chapel Hill

R. Darryl Banks

Senior Fellow

New America Foundation

Max H. Bazerman

Jesse Isidor Straus Professor of Business Administration Harvard University Business School

Alex Beehler

Program Officer, Environment

Charles G. Koch Charitable Foundation

Christopher Bell

Partner

Sidley Austin Brown \& Wood L.L.P.

Jay Benforado

Director, National Center for Environmental Innovation

U.S. Environmental Protection Agency

Bernard Cahill

Program Assistant

Regulatory Policy Program

John F. Kennedy School of Government

Harvard University

Leslie Carothers

President

Environmental Law Institute

Vice President, Environment, Health, and Safety

United Technologies Corporation (retired)

Don R. Clay

Managing Director

Environmental and Regulatory Affairs

Koch Industries, Inc.

Cary Coglianese

Associate Professor of Public Policy

Chair, Regulatory Policy Program

John F. Kennedy School of Government

Harvard University

James Connaughton

Chairman

Council on Environmental Quality

The White House

Terry Davies

Senior Fellow

Resources for the Future

68. See Cary Coglianese \& Lori Snyder Bennear, Program Evaluation of Environmental Policies: Toward Evidence-Based Decision Making, in National Research Council, Panel on Social and Behavioral Science Priorities for Environmental Decision MaKing (Garry D. Brewer \& Paul C. Stern eds., 2005). 


\section{Daniel Edwards Jr.}

Graduate Research Assistant

Department of Public Policy

University of North Carolina, Chapel Hill

\section{E. Donald Elliott}

Partner \& Head, Environment Department

Willkie, Farr \& Gallagher

Professor (Adjunct) of Law

Yale Law School

\section{Ira Feldman}

President \& Senior Counsel

Greentrack Strategies

\section{Daniel Fiorino}

Director

Performance Incentives Division

U.S. Environmental Protection Agency

\section{Beth Graves}

EMS Project Coordinator

North Carolina Department of Environmental Protection

Division of Pollution Prevention and Environmental

Assistance

\section{Bill Hanson}

Associate Director, Office of Business and Community Innovation

U.S. Environmental Protection Agency

John A. Harris

Program Manager, EHS Planning and Development

Ashland Chemical Company

\section{Winston Hickox}

Secretary

California Environmental Protection Agency

Jeffrey R. Holmstead

Assistant Administrator

Office of Air and Radiation

U.S. Environmental Protection Agency

Andrew M. Hutson

Research Assistant \& Doctoral Student

University of North Carolina, Chapel Hill

\section{Jason Scott Johnston}

Director, Program on Law and the Environment

Robert G. Fuller Jr. Professor of Public Law

University of Pennsylvania Law School

Robert A. Kagan

Professor of Law and Political Science

Director, Center for the Study of Law and Society

University of California, Berkeley

\section{Charles W. Kent}

Director

Office of Business and Community Innovation

U.S. Environmental Protection Agency

Robert L. Kerr

Kerr, Greiner \& Associates, Inc.

Andrew King

Associate Professor of Business Administration

Tuck School of Business

Dartmouth College

\section{Paul Kleindorfer}

Professor of Decision Sciences, Economics, and Business

Wharton School

University of Pennsylvania

Debra Knopman

Associate Director

Rand Science and Technology

Kalpana Kotagal

Research Assistant

University of Pennsylvania

Howard Kunreuther

Cecilia Yen Koo Professor of Decision Sciences and

Business \& Public Policy

Wharton School

University of Pennsylvania

Michael Lenox

Associate Professor of Management

Fuqua School of Business

Duke University

Leslie H. Lowe

Program Director, Energy and Environment

Interfaith Council on Corporate Responsibility

Mindy Lubber

Executive Director

Coalition for Environmentally Responsible Economies

Thomas Lyon

Professor of Business Economics

Kelley School of Business

Indiana University

Shelley H. Metzenbaum

Visiting Professor

School of Public Policy

University of Maryland, College Park

Robert P. Minicucci II

EMS Project Manager

New Hampshire Department of Environmental Services

Jason Morrison

Director, Economic Globalization and the Environment

Program

Pacific Institute

Jennifer Nash

Director, Regulatory Policy Program

John F. Kennedy School of Government

Harvard University

Ulku G. Oktem

Adjunct Associate Professor

Wharton School

University of Pennsylvania

Debra Phillips

Team Leader, Responsible Care ${ }^{\circledR}$

American Chemistry Council

Edwin Pinero

Deputy Federal Environmental Executive

Office of the Federal Environmental Executive

Paul Portney

President and Senior Fellow

Resources for the Future 


\section{Tapas K. Ray}

Graduate Assistant \& Doctoral Student

University of Connecticut

Don Reisman

Director, Resources for the Future Press

Resources for the Future

Christian M. Richter

Principal

The Policy Group, LLC

Daniel Roczniak

Director, Implementation and Performance

American Chemistry Council

David W. Ronald

Executive Director

Multi-State Working Group

Susan Rose-Ackerman

Henry R. Luce Professor of Jurisprudence

Yale Law School

\section{William G. Rosenberg}

Senior Fellow

Center for Business and Government

John F. Kennedy School of Government

Harvard University

Lynn Scarlett

Assistant Secretary, Policy, Management, and Budget

U.S. Department of the Interior

Peter J. Schmeidler

Senior Research Fellow

Wharton School

University of Pennsylvania

Kathleen Segerson

Department Head \& Director of Graduate Studies

Department of Economics

University of Connecticut

Betsy Shaw

Director, Office of Environmental Policy Innovation

U.S. Environmental Protection Agency
Jon Silberman

Senior Attorney

U.S. Environmental Protection Agency

Jeff Smoller

Special Assistant to the Secretary of Natural Resources

Wisconsin Department of Natural Resources

\section{Lori Snyder Bennear}

Assistant Professor

Nicholas School of Environment and Earth Sciences

Duke University

Robert Stephens

Assistant Secretary for Environmental Management and

Sustainability

California Environmental Protection Agency

Eric Svenson

Director, Corporate Issues Management

Public Service Electric \& Gas Services Corporation

William L. Thomas, Esq.

Senior Attorney, Office of Compliance Assurance

Pillsbury Winthrop L.L.P.

Barton H. Thompson Jr.

Robert E. Paradise Professor of Natural Resources Law and Vice Dean

Stanford Law School

John Walke

Director, Clean Air Programs

Natural Resources Defense Council

Peter Wise

Principal

Kestrel Management

George Wyeth

Director, Policy and Program Change Division

U.S. Environmental Protection Agency

Terry Yosie

Vice President, Responsible Care ${ }^{\circledR}$

American Chemistry Council

Larry Yuspeh

Director, Research and Development

Louisiana Workers' Compensation Corporation 